\title{
超音速エアブリージングエンジンの再始動制御に関する実験研究*1 Experimental Study on Restart Control of Supersonic Air Breathing Engine
}

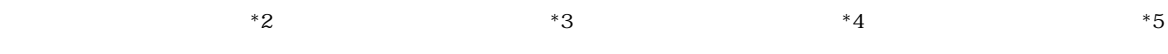 \\ Takayuki KoJIMA, Tetsuya Sato, Shujiro SAwai and Nobuhiro TANatsugu
}

Key Words: Compressible Flows, Control, Inlet, Intake, Unstart, Supersonic Wind Tunnel

\begin{abstract}
In order to study dynamic response and establish control logic of supersonic air breathing engine, restart control tests of subscale engine model, that consists of axisymmetric intake and turbojet engine are done at ISAS supersonic wind tunnel (Mach 3). Assuming the condition that the combustion flame is blown out by the unstart, restart control sequences are set as follows. First, after a wind tunnel is started, the core engine is ignited. Second, the intake is restarted while the core engine is controlled. Third, the intake spike position and the terminal shock position are controlled and intake total pressure recovery becomes the designed value $(60 \%)$. Tests are successful and the engine thrust is recovered for approximately 30-40 seconds after the intake unstart. Sudden increase of combustor flame temperature and rotational speed after the intake unstart is shown experimentally. This phenomenon is inevitable for supersonic engines that apply turbojet cycle as a core engine. To reduce sudden increase of the flame temperature, new sequence to close a fuel control valve after detection of the intake unstart is done and an increase of the flame temperature is reduced. Furthermore, necessity of avoidance of the intake buzz is shown experimentally. To avoid the intake buzz, 'buzz margin' control by the bypass door is proposed and succeeded.
\end{abstract}

\section{記 号 の 説 明}

$m_{0}$ : カウル前方投影面積分を通過する主流空気 流量

$m_{1} \quad:$ インテーク捕獲空気流量

$A_{1} \quad$ : インテーク出口状態における仮想閉塞面積

$A_{\mathrm{by}} \quad$ : バイパスドア流路面積

$A_{\mathrm{pl}} \quad:$ 背圧調整用プラグ流路面積

$B M \quad$ : バズマージン

$E R \quad$ : 当量比

$F_{\text {noz }}:$ ノズル理想推力

$F_{\text {in }} \quad:$ インテークに流入する空気流の運動量

$I S P_{\text {noz }}$ : ノズル理想推力より求めた比推力

$I S P_{\text {net }}$ : 正味推力より求めた比推力

$N \quad$ : エンジン回転数

$M_{0} \quad$ : 主流マッハ数

$M C R \quad$ : インテーク流量捕獲率

$M C R_{\mathrm{B}} \quad:$ バズが発生する時のインテーク流量捕獲率

$P_{\mathrm{t} 0} \quad:$ 主流全圧

$P_{\mathrm{t} 1} \quad:$ インテーク出口全圧

TC : 燃焼ガス温度

$Q_{\text {cnd }} \quad$ : 燃料流量調節弁開度指令

$T P R \quad:$ インテーク全圧回復率

$T P R_{\mathrm{B}} \quad:$ バズが発生する時のインテーク全圧回復率

$X_{\mathrm{sp}} \quad$ : スパイク位置

${ }^{* 1} @ 2002$ 日本航空宇宙学会

平成14年7月23日原稿受理

${ }^{* 2}$ 宇宙科学研究所COE研究員 (宇宙推進研究系)

*3宇宙科学研究所助教授 (宇宙推進研究系)

*4宇宙科学研究所助手 (システム研究系)

*5宇宙科学研究所教授 (宇宙推進研究系)
1. はじめに

将来の極超音速航空機用および宇宙往還機（スペースプ レーン) 用の推進システムとして , 地上からマッハ数6程 度まで作動する空気吸い込み式エンジンの実現か期待され ている ${ }^{1 \sim 3)}$ ，宇宙往還機に利用されるエンジンは，航空機 と比較した場合，光の使用目的より設計および運用に関す る仕樣が異なる．すなわち，宇宙往還機は，航空機のよう に移動 (巡航) することではなく，加速することが目的で ある. 従って，(1)航続率のような距離に関する性能より も，比推力や推重比のような重量に関する性能が重要視さ れ，(2)常に最大推力で作動し，(3)加速飛行を主とするた め, 明確な設計点 (定常飛行状態) が存在しないといった 特徵がある。

さらに，極超音速エアブリージングエンジンに用いられ るインテークを従来の超音速インテークと比較した場合， 最も明確な差は飛行領域の拡大である . 飛行速度の増大に 伴い，インテークの超音速流路収縮率（三内部圧縮流路入 口面積/スロート面積) が大きくなるため，不始動による全 圧回復率，流量捕獲率の低下が大きくなり，推進機関とし て推力, 比推力の低下か顕著になる . 極超音速エアブリー ジングエンジンにとって , インテーク不始動は致命的なダ メージを与える．

エンジン制御の観点からは，機体の加速度が大きく主流 流速の変化率が大きい中で, 常に最大推力での作動が要求 されるため，制御に対する要求が厳しくなる．エアブリー ジングエンジンはインテークの全圧回復率が高いほど大き な推力が得られるが, 全圧回復率はインテークか始動から 不始動入遷移する限界において最も高くなる．このため， 不始動に陥る可能性が高い，さらに，もしインテークが不 


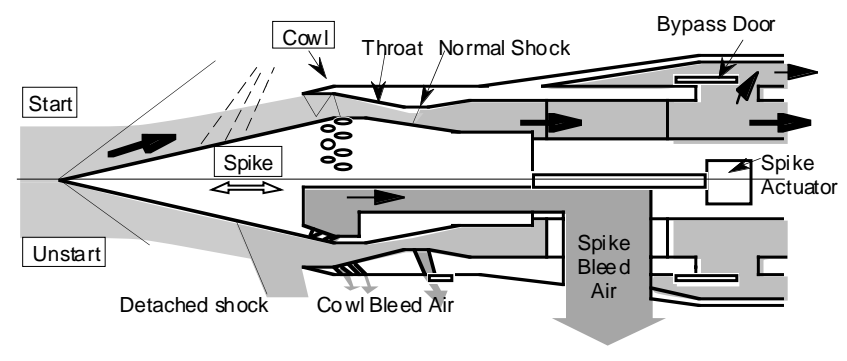

第1図 軸対称インテーク

始動に陥つた場合，素早く再始動させ，推力を回復させな ければミッションの失敗に繋がる゙ャ5.

宇宙科学研究所では, 飛行マッ八数6において分離する二 段式宇宙往還機の初段推進系として，エア・ターボ・ラム ジェットエンジン (ATREXエンジン) の開発研究を行って いる.このエンジンは, コアエンジン前方に設けられた空 気予冷却器と燃焼室内に配置された熱交換器によって液体 水素燃料を再生加熱し，弚のエネルギでタービンを駆動す るエキスパンダサイクルを構成した空気吸い込み式エンジ ンである.ATREXエンジン用インテークの研究は, 1993年 より行われ，エンジン制御に関する研究は1998年より行わ れている6 8).

これらの背景を踏まえ，本論文ではATREXエンジンのよ うに最大飛行マッ八数6まで作動する極超音速エアブリージ ングエンジンの制御，特に効果的な再始動方法を構筑する ことを目的として研究を行った結果について述べる．イン テークの再始動ロジックを構筑するためには, まず第一に 不始動に陥った時の挙動を調査する必要があるが，イン テーク不始動に伴う現象は非定常性が強く，解析的な予測 は難しいと思われる . 乥こで, 本研究は不始動によるエン ジン挙動を調査する第一段階として, 超音速インテークと 小型ターボジェットエンジンを用いたサブスケールの超音 速エアブリージングエンジンモデルを構築し, 超音速風洞 において制御実験を行った。

\section{2. 軸対称インテーク}

飛行マッ八数6程度の極超音速飛行に用いられるインテー クは, 機速の上昇に伴い衝撃波角が小さくなるため, 既に 実用化されている飛行マッハ数 2 程度のインテークと比較し
て直径・長さが大きくなり，この結果エンジン全体重量に 対するインテーク重量の割合が大きくなる .このため宇宙 往還機のような加速機においては，インテークの空力的な 性能向上と同樣に重量を軽減することが重要である，弚こ で, 矩形形状に比べて重量軽減が行いやすい混合圧縮型軸 対称形状をATREXエンジン用インテークとして採用してい $3^{9,10)}$. 第1図に本研究で対象とした可変軸対称インテーク の概念図を示す . 図中の衝撃波構造は，上側がインテーク 始動時を表し，下側が不始動時を表す、軸対称インテーク はスパイク (センターボディ) とカウルより構成され，ス パイクが前後移動する可変機構を備え, 流路形状, 流路収 縮率を変化させる .

インテークの性能は，以下に定義される全圧回復率およ び流量捕獲率によって定義される。

$$
\begin{gathered}
T P R \equiv \frac{P_{t 1}}{P_{t 0}} \\
M C R \equiv \frac{m_{1}}{m_{0}}
\end{gathered}
$$

超音速飛行時にインテークが始動している場合は, 全圧 回復率を高く保つようにスパイクの位置を調節するため， カウル内部に取り込まれる空気流量は一義的に決まる。一 方, 覀音速および遷音速飛行時は, 可能な限りインテーク のスロートを大きく開き，最大空気流量を取り込むように 制御される.このため, 全ての飛行マッ八数において, イ ンテークに吸い込まれる流量が, コアエンジンに要求され る流量と常に等しくなるようなインテーク形状を設計する ことは困難であり，このためインテーク始動時は, コアエ ンジンに要求される流量よりもやや多めに空気を取り込 み, 余剩流はバイパスドア (または抽気機構)により調節 する．このため，インテーク始動時に，バイパスドアによ る余㮃流の制御に失敗すると，インテークが不始動へ陥 る、インテークが不始動に陥ると，スパイク先端衝撃波と カウル前方へ飛び出した離脱衝撃波によって流れが亜音速 へ減速されるために, 大きな全圧損失が発生し，このため スロートを通過できる空気流量か制限されることにより捕 獲空気流量が減少する、不始動になると，エンジンか摊進

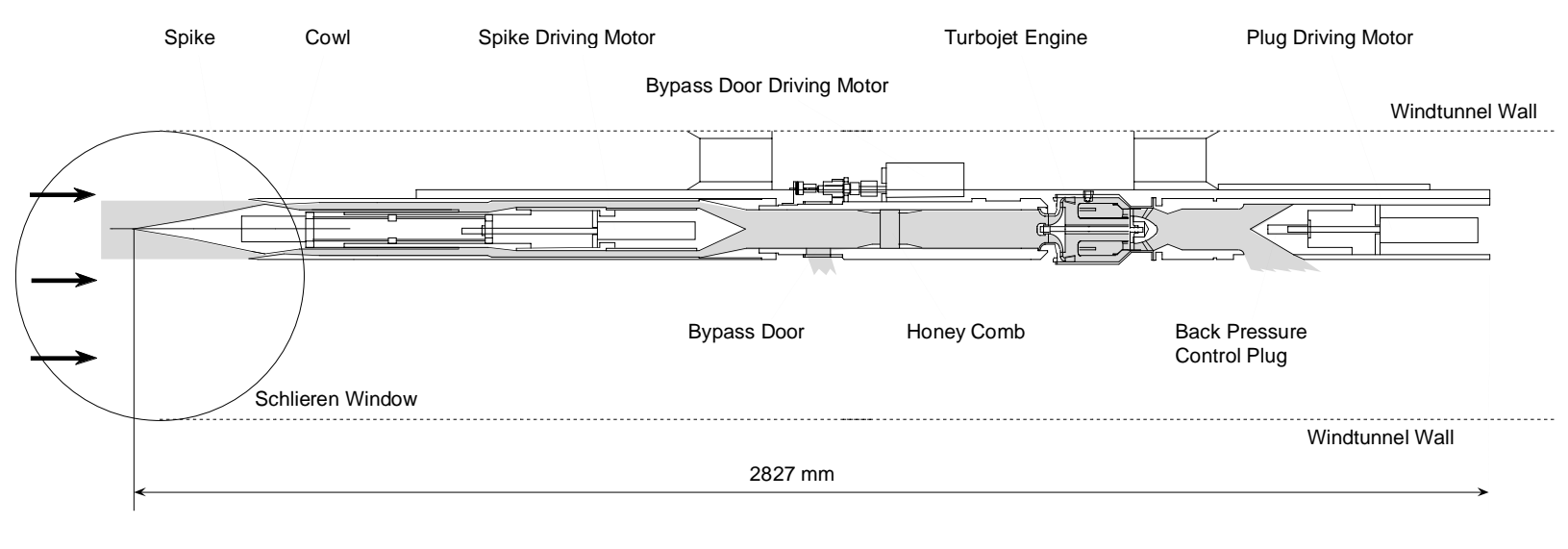




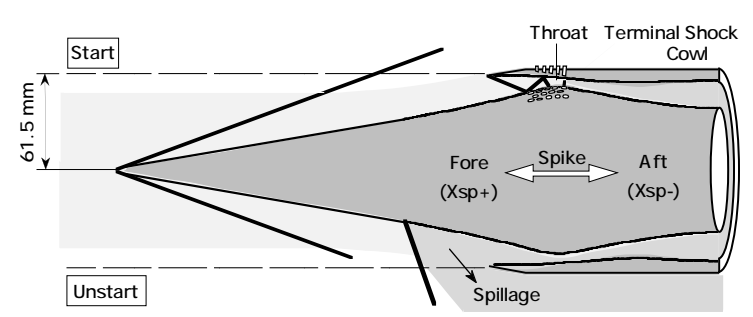

第 3 図 供試インテーク形状 $\left(X_{\mathrm{sp}}=0\right)$

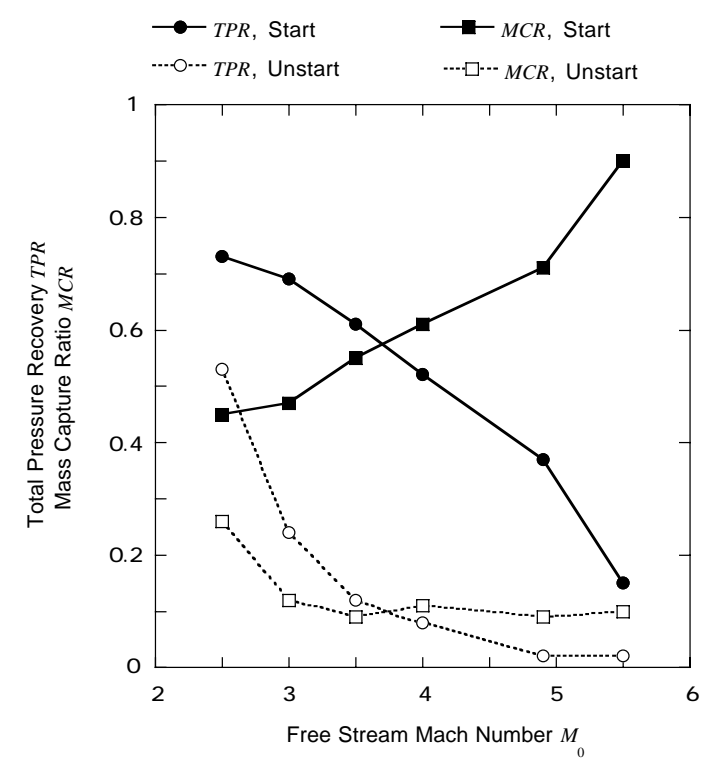

第4図インテーク性能

第1表 供試インテーク諸元

\begin{tabular}{cc}
\hline Intake type & $\begin{array}{c}\text { Variable geometry, } \\
\text { Axisymmetric }\end{array}$ \\
\hline Design Mach number & M3.5 \\
\hline $\begin{array}{c}\text { Shock on cowl lip } \\
\text { Mach number }\end{array}$ & M5.3 \\
\hline Cowl inlet radius & $61.5[\mathrm{~mm}]$ \\
\hline Spike tip - cowl inlet distance & $\begin{array}{c}241.7[\mathrm{~mm}] \\
\text { (at Design Mach number M3.5) }\end{array}$ \\
\hline Cowl inlet - throat distance & $\begin{array}{c}49.2[\mathrm{~mm}] \\
\text { (at Design Mach number M3.5) }\end{array}$ \\
\hline
\end{tabular}

機関として有効な推力を発生しなくなるため, インテーク 不始動回避のための制御および不始動時には迅速な再始動 制御が必要である.インテークを再始動させるためめには， スパイクを大きく前方へ動かし，収縮率を低下させる必要 がある．インテークが始動から不始動へ遷移する収縮率 と, 不始動から再始動する収縮率には数倍の差があり，始 動不始動現象はヒステリシスを伴う現象である .

\section{3. 実 験 装 置}

制御実験には, 軸対称インテーク , バイパスドア , ター ボジェットェンジン, 背圧調整用プラグより構成される， 超音速エアブリージングエンジンモデルを用いる . 第2図に 実験供試体の全体図を示す．以下に , 各コンポーネントに
ついて記述する．

3.1 インテーク ${ }^{8} 10$ 実験には第3图に示すような軸対 称インテークを用いる . 図中上側が設計時の衝撃波構造 （始動）を示し，下側が不始動時の衝撃波構造を示す．イ ンテークの主要諸元を第1表に示す . インテークの大きさ は, カウル入口半径=61.5mmであり, スパイク先端からイ ンテーク出口 (拡大流路最後端) までの距離はスパイク前 後移動によって変化し，393〜430mmである. 本論文中で は, スパイク位置 $X_{\text {so }}$ (カウルとスパイクの相対位置関係) を以下のように定義する . インテークの設計点であるマッ 八数3.5において, 最適なスパイクとカウルの相対位置をス パイク位置原点 $\left(X_{\mathrm{sp}}=0\right)$ とし, 乥こからスパイクを前方 (上流側) へ動かす向きを正とする．超音速ディフュー ザ一流路形状の設計方法は, まず最大マッハ数5.3 (shock on cowl lip マッ八数) のときに , スパイク先端から発生す る斜め衝撃波がカウル先端部に入射するように，スパイク 先端部からカウル入口部までの距離を定めた後, マッハ数 3.5を設計マッ八数として，特性曲線法により設計した . 本 インテークは, 地上静止状態からマッ八数6までの範囲て作 動することを想定しているが，機体予圧縮効果を考えて， インテーク上流における最大マッ八数を5.3としている.ス ロート周辺のスパイク , カウルの壁面には, 直径 $1 \mathrm{~mm} の$ 抽 気孔か計5280点開けられており，これらの穴より境界層内 の気流を抽気し，剥離を防ぐ、インテーク始動時に，スパ イク先端〜スロート部において行われる超音速圧縮のディ フューザー形状は, 主流マッハ数に応じてスパイクを前後 させることにより最適な形状へと制御される．これによっ て , スロートにおけるマッ八数が常にM1.3程度に保たれ る、流れを亜音速へ減速する終端衝撃波は，インテーク出 口流路を調節し全圧回復率を変化させることにより前後へ 移動するが，終端衝撃波がスロート部に存在する時に全圧 回復率が最大となる.終端衝撃波がスロートより上流へ移 動するとインテークが不始動になる．インテーク不始動を 防ぐため終端衝撃波は常にスロート直後に制御される。

収縮率が上昇し（スロートが狭くなり），スロート上流 側におけるマッハ数がM1を下回るか, または終端衝撃波が スロート前方へ飛び出すと, 数ミリ秒の間に作動状態が不 始動に遷移する．インテーク始動時および不始動時の全圧 回復率, 流量捕獲率を第图に示す. 高マッ八数において, 不始動による性能低下力顗著になる．

3.2 バイパスドア 始動時にカウル内部に取り込まれ る空気流量は, 主流状態とスパイク位置によって決定され るが, 飛行状態によって, 圧縮機か処理できない過大な流 量となることがある.インテークと圧縮機の流量マッチン グは光のほとんどか設計段階で行われるが, 飛行中にも少 量の余剩空気を外入逃がす機構が必要である.これは，イ ンテーク始動時には不始動を防ぐための終端衝撃波位置制 御機構として働き，インテークが不始動の場合は，再始動 させるためにインテーク出口圧を下げる機構として働く . 本研究では, この機構をバイパスドアと呼ぶこととする . 本実験供試体では，バイパスした気流は風洞主流に放出す 
るため, バイパスドア出口には超音速の風洞主流が流れて おり，流量係数が低くなることが予想された．このため， バイパスドアの面積を大きめにとれるように , 第5図に示す ような半円形状のものとした . また , バイパスドアによっ て生じた圧縮機入口部の非一樣流れを緩和するために , バ イパスドアとコアエンジンの間に整流ハニカムを設けてい る。

3.3 エンジン11 13) エンジンは小型ターボジェットエ ンジンである，AMT社 (オランダ) 製オリンパスエンジン を用いる. 本エンジンはラジコン飛行機用に開発されてい るものである . 第6図にエンジン全体図および地上設置時の 写真を示す . また，第2表に示すように蒸発管方式の燃焼器 となっているために, 燃料の着火性に乏しい .このため、 着火時にプロパンガスを用いることにより，確実な燃料着 火を行っている.

3.4 背圧調整用プラグ エンジンの出口圧力を調節す るために, 背圧調整用フロープラグを設けている .プラグ スロートにおいて, 常に流れか閉塞しているために, 収縮 拡大ノズルをつけた場合とエンジン内部の流れは同樣にな る.

\section{4. 制御ロジック}

本制御実験における制御ロジックを第7図に示す．イン テーク始動時は，4入力（インテークスロートマッハ数・ 終端衝撃波位置・回転数・燃焼ガス温度) 4出力 (スパイ ク移動指令・バイパスドア移動指令・燃料流量調節弁開度 指令・背圧調整用プラグ移動指令) のフィードバック制御 を構成するが , 以下の理由によりフィードバックループを 3つに分割する . (1)インテーク終端衝撃波より上流側は超 音速流であるため，下流側の情報が伝達されず，インテー クスロートマッハ数は主流流速, 迎角, スパイク位置のみ により決定される。よって，スパイク移動以外の制御指令 でスロートマッハ数は制御できない . (2)バイパスドアを開 くとコアェンジンに供給される流量が低下し，エンジン推 力が低下する .このため , バイパスドアは極力開くべきで はなく，不始動回避のみの目的で行うべきである．イン テーク始動時におけるバイパスドアの役割は，終端衝撃波 がスロートより前方へ移動することによる不始動遷移の防 止であるため，バイパスドアの制御対象は終端衝撃波のみ とするべきである . (3)始動，不始動の制御が切り替わると きの衝撃を緩和するために，コアエンジン部の制御はイン テークスロートマッハ数制御, 終端衝撃波位置制御とは分 離し，始動，不始動時共通な制御を行うべきである．

以下にインテーク始動時不始動時における光れ光れの フィードバック制御について記述する .

4.1 インテーク制御 インテークが始動している時 は, スパイク前後移動により, スロートマッハ数を制御す る . 本供試体は , インテークのスロート (幅) 高さが小さ いために，インテークスロートにピトー管を設けてマッハ

第2表 オリンパスエンジン諸元
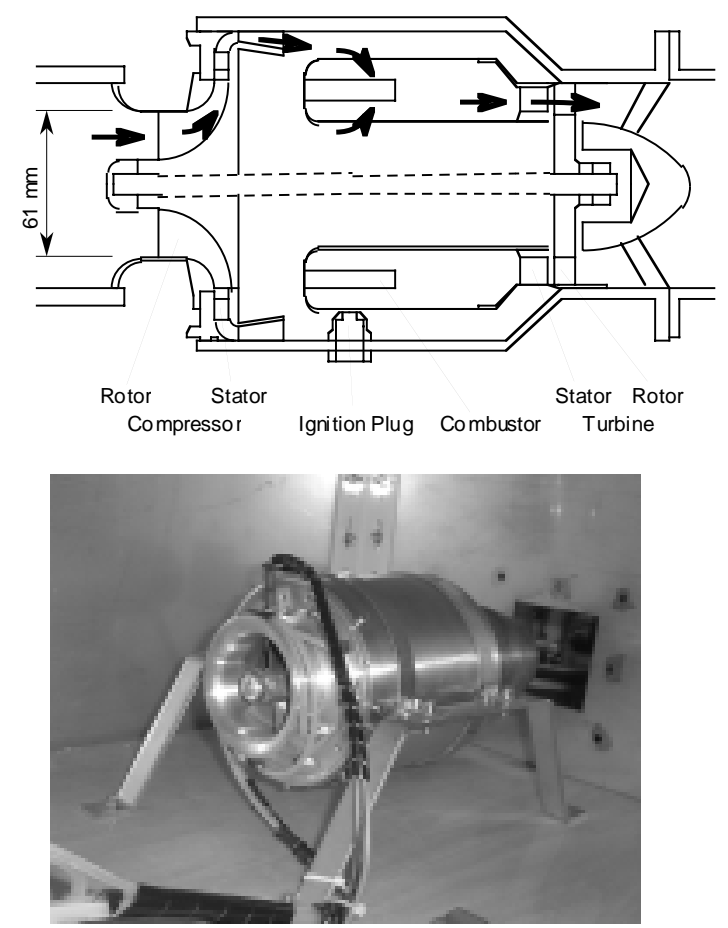

第6図 AMTオリンパスエンジン

\begin{tabular}{cc} 
第2表 & オリンパスエンジン諸元 \\
\hline Outer diameter & $130[\mathrm{~mm}]$ \\
\hline Total length & $270[\mathrm{~mm}]$ \\
\hline Thrust & $170[\mathrm{~N}]$ (Max.) \\
$7[\mathrm{~N}]$ (ldle)
\end{tabular}




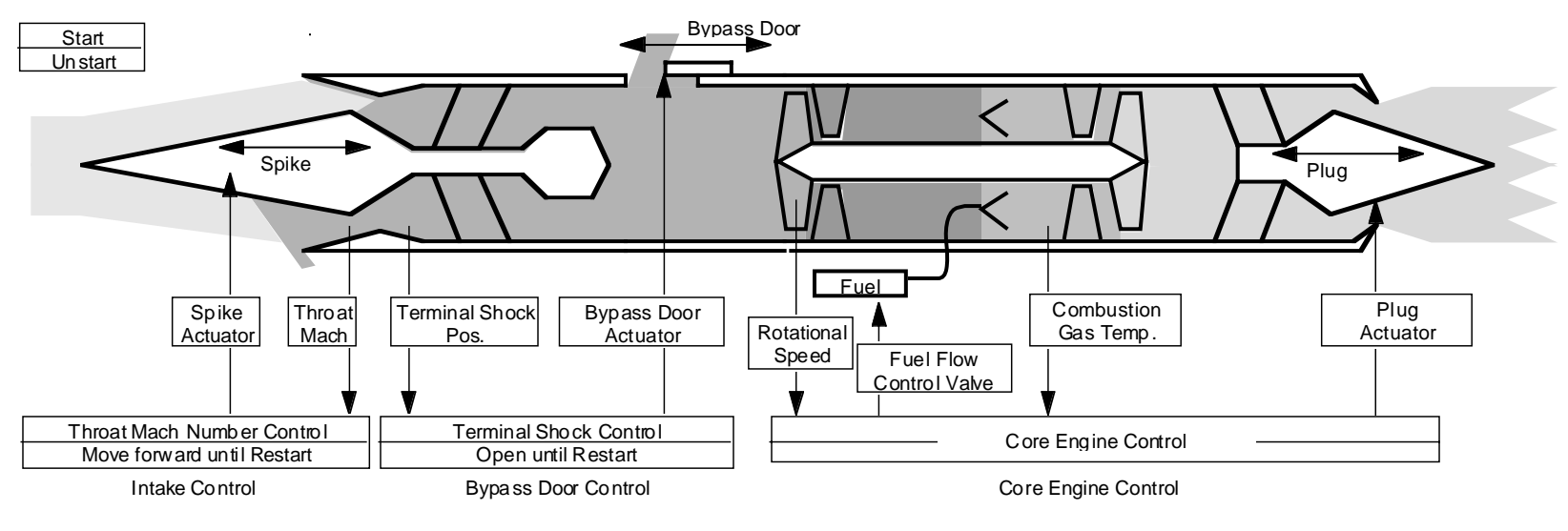

第7 図 供試体制御ロジック

数を計測すると，ピト一管によって生じるバウショックに よりインテークの全圧回復率が大幅に減少する．また，本 制御実験では, 主流マッハ数が固定されているために , ス ロートマッハ数が最適となるスパイク位置は一定である. よって , 実験はスロートマッハ数の代わりにスパイク位置 を検出し，あらかじめ求められた目標位置へスパイクを移 動する，不始動時は, スパイクは再始動位置まで前方（上 流側) へ一定速度で移動する。

4.2 パイパスドア制御 インテークが始動している 時は，バイパスドアは終端衝撃波位置を制御する．本制御 実験では，終端衝撃波位置と全圧回復率の関係をあらかじ め求めておき, 全圧回復率を制御目標值にする . インテー ク不始動時には, あらかじめ求められた再始動開度まで一 定速度で開く．また，6.4節において記述するバズマージン 制御を実験中に取り入れた。

4.3 コアェンジン制御 コアェンジンの制御は燃料 流量 , プラグスロート面積を制御量として, エンジン回転 数, 燃焼ガス温度 (タービン入口温度) を制御する 2 入力 2出力フィードバック制御を行う.

弚れ光れの制御則は, PI制御を行い, 制御ゲインはエン ジンダイナミックシミュレーションにより求めた線形化モ デルを使用して安定性, 追従性を確認している .シミュ レーションは, 予備実験によって取得した各コンポーネン ト (インテーク・バイパスドア・圧縮機・燃焼室・タービ ン・背圧調整用プラグ）の静特性および動特性より，常に 気体力学的状態変化, 燃焼反心には遅れは発生せず, エン ジン回転数が圧縮機とタービンの仕事差によって時間变化 する計算を行っている . 燃焼ガス温度は燃料流量指令に対 する感度が大きいが, 燃料供給方式に蒸発管を使用してい るため火炎温度が安定せず, 燃料流量制御のゲインが低く なっている．

\section{5. 試 験 方 法}

実験は宇宙科学研究超音速風洞において行った . 風洞条 件の制約により, 主流マッハ数3, 主流全圧 $4.5 \mathrm{~kg} / \mathrm{cm}^{2} \mathrm{a}$, 主 流全温293K, 通風時間90secの条件で行った . 主流マッハ数 3では, 第4図に示したようにインテーク不始動による性能 低下か顕著に現れるため, インテーク不始動時のエンジン の挙動や, 効果的な再始動方法について研究を行うために
十分高速な領域である . 制御実験は, 飛行中にインテーク が不始動となり, 火炎が吹き消えた状態を想定して行う. よって，インテークが不始動になるようスパイクを後方へ 下げ (スパイク位置 $X_{\text {sp }}$ 小さくし) た状態で風洞通風を開 始する . 通風後エンジンを着火し , 燃焼中にインテークを 再始動させ , インテーク全圧回復率を最大とするまでの自 動制御を行う (再始動制御実験) 。

本エンジンは, 蒸発管方式の燃焼室のため, 燃料着火性 能に乏しい．このため, エンジンをスタートさせるために はまずプロパンガスに着火させ , 蒸発管を加熱した後に燃 料の供給を開始する . プロパンガスへ着火させるために は, 地上静止状態におけるエンジン起動を模擬させる必要 があり, エンジン内に微量の空気が供給され，圧力をほぼ 大気圧 (もしくは大気圧以上) とする必要がある．このた め, 背圧調整用プラグを微開状態とし，コアエンジンへの 空気の供給がほとんど行われない状態において , プロパン ガスに着火させる .

計測は各部全圧・静圧の圧力計測, TypeK熱電対による 温度計測，ポテンショメータによる位置計測，体積流量計 による燃料流量計測を行っている. 計測值は0.02secサンプ リングの制御器に入力され, 制御指令が求められる.

\section{6. 実 験 結 果}

6.1 再始動制御実験 第8図～第11図に再始動制御実 験を行った実験結果を示す . 第8図中当量比 $E R$ は燃料と空 気の質量流量比率を理論反応比率で割った值であり，燃料 と空気が過不足無く燃焼する流量比率が当量比1である.第 11図中ノズル理想推力 $F_{\mathrm{noz}}$, 比推力 $I S P_{\mathrm{noz}}$ は背圧調整プラグ 部に, 適正膨張でありノズル効率100\%である理想ノズルを 装着したと仮定した場合の推力を表す .さらに , インテー ク流入運動量 $F_{\text {in }}$ は, インテーク上流から流入する空気流の 運動量である . インテークが始動している時は , インテー クのスピレージ抵抗は微少であり， $\left(F_{\mathrm{noz}}-F_{\mathrm{in}}\right)$ がエンジンに 働く正味推力にほほ等しい.さらに, 正味比推力 $I S P_{\text {net }}$ は正 味推力 $\left(F_{\mathrm{noz}}-F_{\mathrm{in}}\right)$ を燃料流量で割った值である .

再始動制御実験は, まず風洞通風開始直後プロパンガス に着火させ(5sec)，燃焼室温度を上昇させる．燃焼室温度が 安定し, 蒸発管が十分加熱されたことを確認した後, 燃料 を供給し回転数を上昇させる(21sec)．この間，スパイク， 
バイパスドアは固定し , プラグを少しずつ開くことにより エンジンに供給される空気流量を増やしていく．回転数が 35000rpmを達成した時に，エンジン着火シーケンスを終了 し，インテーク再始動に向けた制御を開始する(42sec) . 再 始動へは, スパイクを前へ(スパイク位置 $X_{\mathrm{sp}}$ を正の方向 へ）動かし，同時にバイパスドアを開く．この間，コアエ ンジンのフィードバック制御が行われ，目標回転数 65000rpm, 目標燃焼ガス温度865K八制御される . スパイ ク , バイパスドアが所定の位置への移動を完了すると，イ ンテークが始動したと判断し(60sec), スパイク位置, バイ パスドア開度は始動モードの制御となる．インテークか始 動すると，スパイク位置のフィードバック制御が始まり， 徐々に後ろ (スパイク位置 $X_{\mathrm{sp}}$ を負の方向へ) へ移動する . またバイパスドアは終端衝撃波がスロート部に移動するよ

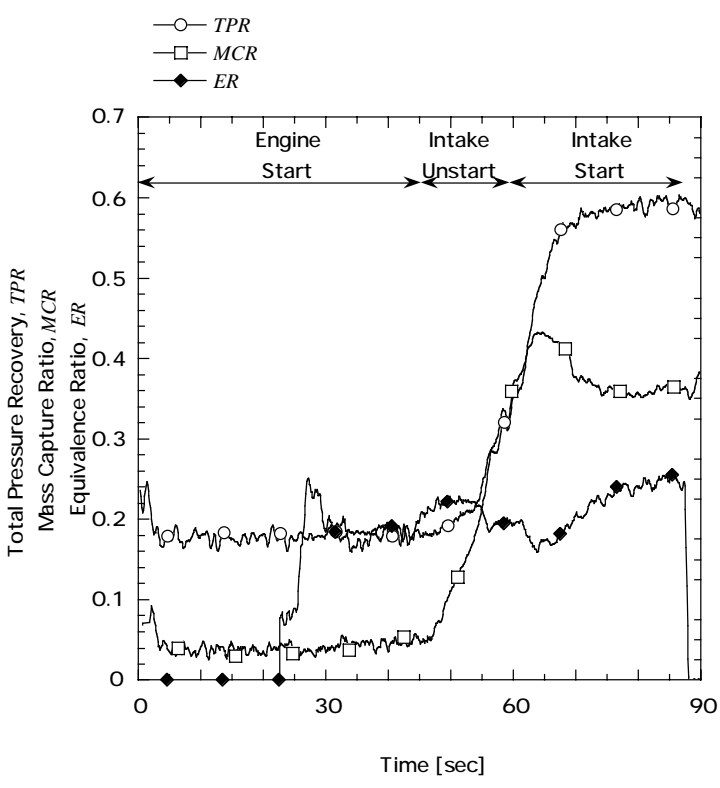

第8図再始動制御実験結果（インテーク・燃焼器）

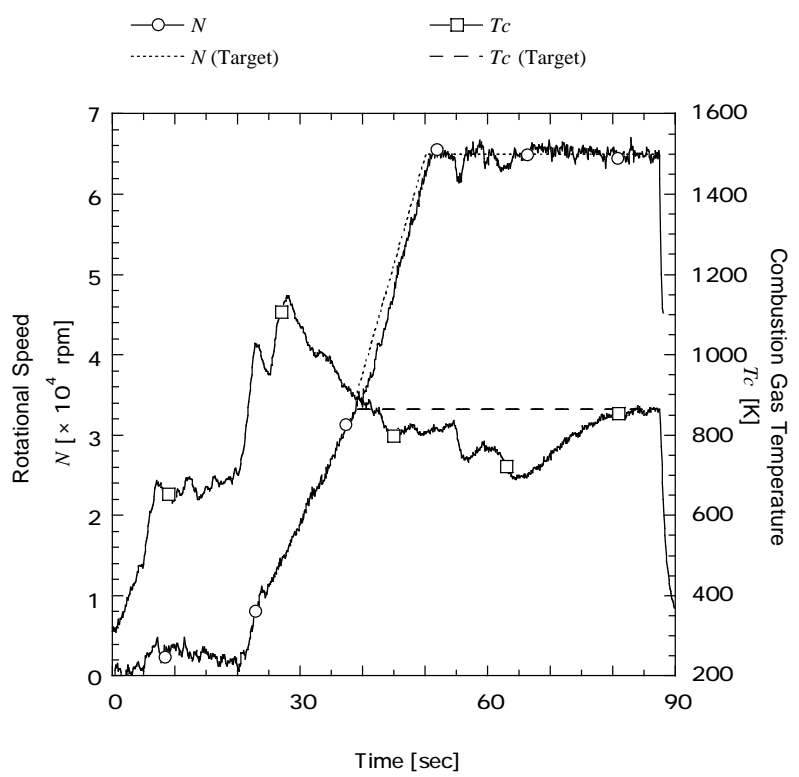

第9図 再始動制御実験結果（回転数・燃焼ガス温度 )
うに徐々に閉じる .これにより，全圧回復率が目標値(60\%) となり，理想推力 $F_{\mathrm{nor}}$ が最大となる $(87 \mathrm{sec})$. この時，理想推 力 $F_{\text {noz }}$ が流入運動量 $F_{\text {in }}$ を上回り，エンジンが正味推力を発生 していることがわかる.制御安定後，エンジンを停止し， 風洞通風を終了する(90sec)：これにより，インテーク不始 動後の再着火 , 再始動が可能であることが示された . 飛行 中にインテークが不始動へ遷移し，不始動の衝撃により燃 焼室の火炎が消えてしまった場合は, 数秒以内で再着火を 行い再始動に向けた制御を開始する必要がある．本制御実 験では再始動を行う制御は45sec時に開始し，再始動後 $75 \mathrm{sec}$ 時には十分な正味推力を回復しており，再着火後約 30secて推力回復が行われている.よって，実機の再着火に 要する時間を考慮すると，不始動後少なくとも30４0secで 推力回復が可能であることが示された .これは , 二段式宇

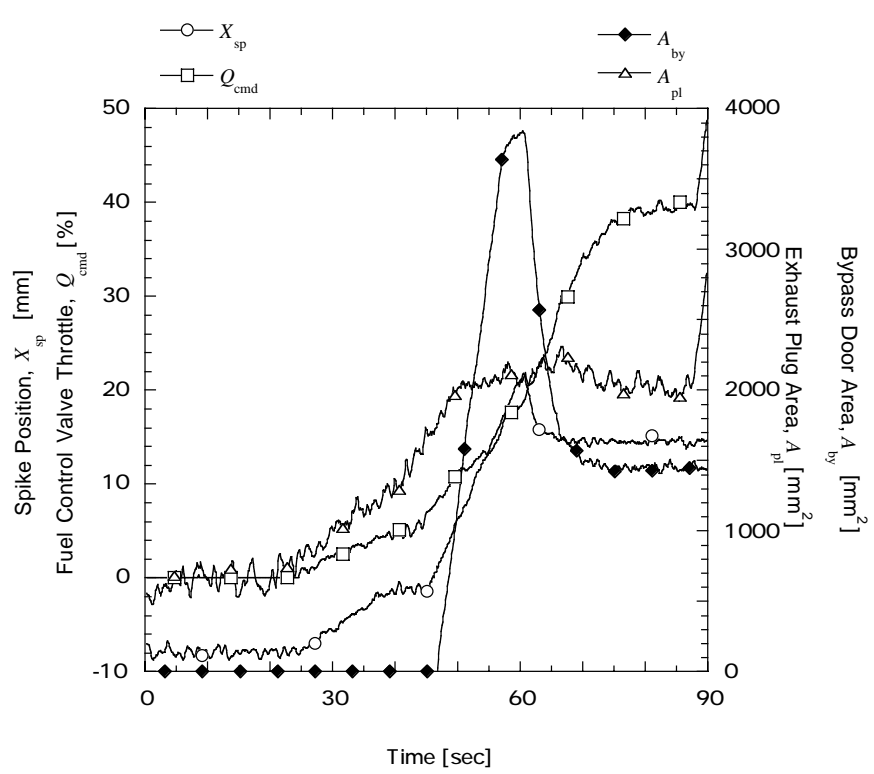

第10図 再始動制御実験結果（燃料流量・面積）

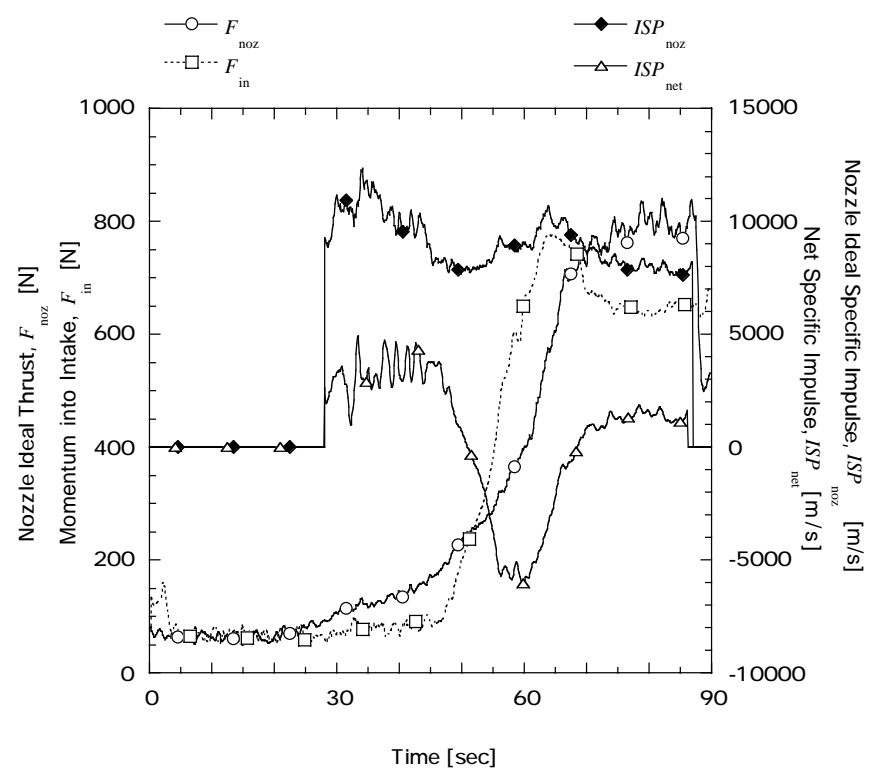

第11図 再始動制御実験結果（理想推力・比推力 ) 
宙往還機のように数分て離陸からM6程度まで加速する機体 にとって迅速な再始動制御とは言い難い，しかし，本制御 実験において低速な制御となってしまった理由は, 燃焼室 の燃料気化機構に蒸発管を用いているため, 燃焼ガス温度 制御の応答性が悪いためである．このため，燃料供給方式 やアクチュエータ等ハードウェアの改善により, より高速 な再始動制御が可能であると思われる.

6.2 不始動直後のエンジン挙動 再始動制御実験に おいて, インテークか始動し制御か安定した後，スパイク を故意に後ろへ動かしインテークを不始動へ遷移させた時 のエンジンの挙動を調ベた 、インテークが不始動へ遷移し た直後における燃焼ガス温度および回転数の挙動をダイナ ミックシミュレーション結果と共に第12図，第13図に示 す . 図中1sec時にインテーク不始動が発生している.第4図 に示すように, インテークが不始動になると, 全圧回復 率, 流量捕獲率共に数分の 1 まで低下するが, 流量捕獲率 が低下することにより，燃焼室における当量比が急激に増 大する.コアェンジンにターボジェットエンジンを採用し ている極超音速エンジンの場合, タービン入口温度の制約 により, 燃焼室の当量比は0.2 0.3程度で運転される.この ため, インテーク不始動による当量比増加は燃焼ガス温度 の増加をもたらす . 図中実線はシミュレーション結果を表 し, シミュレーションでは燃焼効率を100\%としたため，燃 焼ガス温度が800Kから2400K程度まで跳ね上がっている。 一方, $\square$ 印は実験結果を表し, 燃焼効率の影響や温度セン サの応答遅れにより，不始動後1sec間の上昇は200K程度と なっている．実験では燃焼ガス温度制御のゲインが低いた め，不始動直後の温度上昇を制御することができず， ター ビン入口温度上限を上回り非常停止を行っている $(2.4 \mathrm{sec}$ 時・1073K) ，乥こで，流量捕獲率の急激な低下によって 不始動を検出し, 不始動検出後は, 燃焼ガス温度のフィー ドバック制御を中断し，強制的に燃料調節弁を遮断する制 御を行った (○印) .これにより，燃焼ガス温度は不始動 後200K程度上昇しているが, タービン入口温度上限に触れ ることなく，不始動後1sec時には減少に転じている．

燃焼ガス温度か増加すると, タービン仕事の増大により 回転数が上昇する。これにより，圧縮機のサージ発生の可 能性が高まる. 不始動直後に燃焼ガス温度が上昇しタービ ン損傷を招き，さらに圧縮機サージが発生するという特性 は，コアエンジンにターボジェットを用いる極超音速エア ブリージングエンジンの特性であるといえる .

6.3 不始動時におけるバズ回避 インテークが不始 動から再始動へ移行する時における，インテーク性能マッ プ (流量捕獲率・全圧回復率関係图) の変化を第14图に示

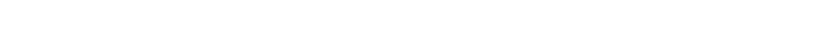
パイク位置 $X_{\text {sp }}$ 表す) において, プラグを固定，バイパス ドアを全開から徐々に閉じるとインテーク出口修正流量が 減少し，インテーク不始動状態 (実線) からバズ状態 (破 線) 一移行する . バズ発生時のシュリーレン映像を第15図 に示す， バズが発生すると，カウル前方に生じる離脱衝撃 波が大きく振動し，燃焼火炎が消炎することがあった（第 14図中×印) .このため , バズの回避はインテーク不始動
中の重要課題であり，常にバズライン (太い破線) より右 下の領域で作動させなくてはならない .

インテークバズはカウル入口部で発生する振動現象であ るが , バズ発生の条件はインテーク出口条件において流れ か閉塞する仮想的なスロート面積，つまり修正流量に依存 する5) .よって, 修正流量と比例する (流量捕獲率/全圧 回復率) の值を表すことにより，バズ発生の危険性を表す ことが可能である .

$$
A_{1} \propto \frac{m_{1}}{P_{t 1}}=\frac{m_{0}}{P_{t 0}} \frac{M C R}{T P R}
$$

バズを回避するための積極的な制御として , バズマージン という制御目標をバイパスドアで制御することを提案し
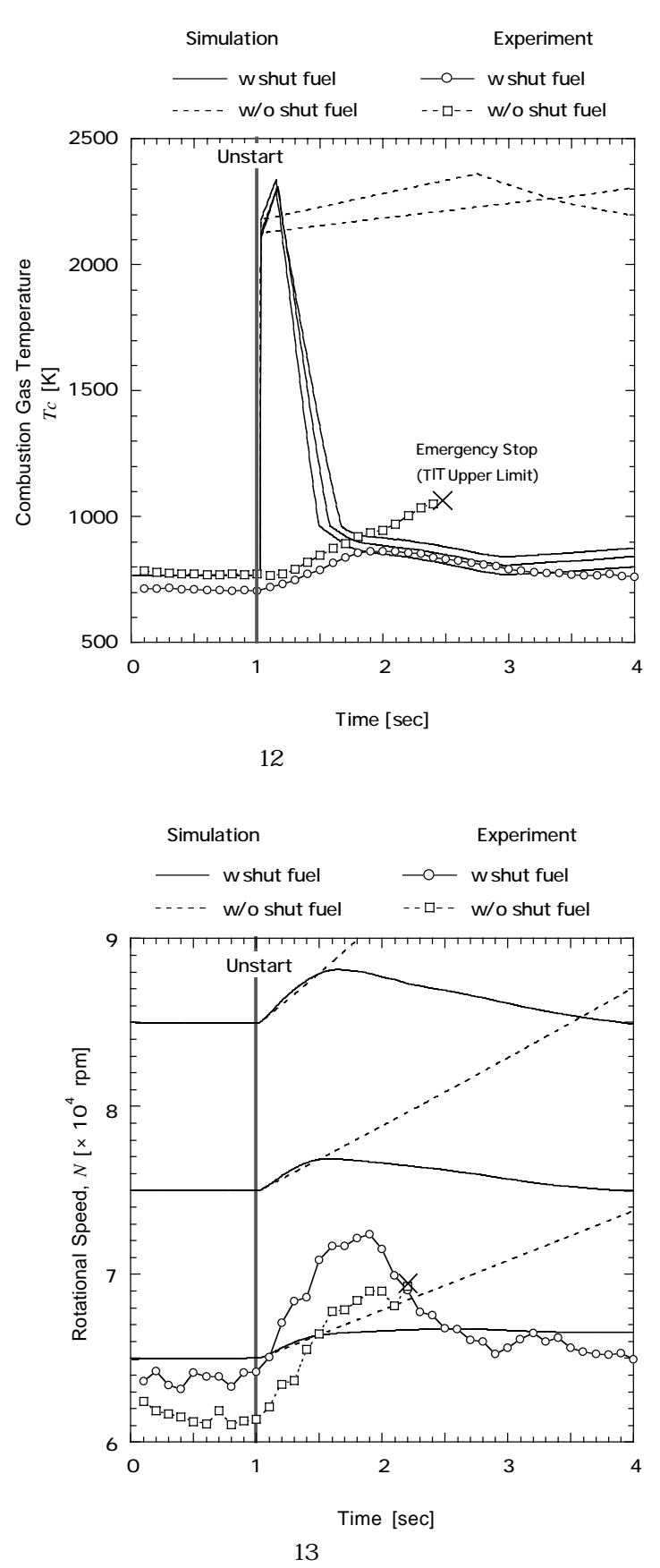
た . バズマージン $(B M)$ の定義を以下に示す . バズマージン が1を下回るとバズが発生する .

$$
B M \equiv \frac{M C R}{T P R} \frac{T P R_{\mathrm{B}}}{M C R_{\mathrm{B}}}
$$

$T P R_{B}, M C R_{B}$ はバズが発生する全圧回復率 , 流量捕獲率を表 し, スパイク位置によって変化する。

$$
\begin{aligned}
& T P R_{\mathrm{B}} \equiv T P R_{\mathrm{B}}\left(X_{\mathrm{sp}}\right) \\
& M C R_{\mathrm{B}} \equiv M C R_{\mathrm{B}}\left(X_{\mathrm{sp}}\right)
\end{aligned}
$$

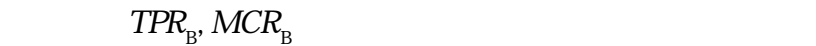
ズが発生する境界 (第14図中バズライン) を表す．本制御 実験では，バズマージンの制御をバイパスドアによって行 い，バズを回避した再始動に成功している（○印）．バズ マージンをモニターすることにより，インテーク不始動時 のバズ発生の危険性を認知し，バズ回避の積極的な制御が 可能である .

\section{7. 結 論}

極超音速エアブリージングエンジンの始動不始動時にお ける挙動を調べ, 制御方法を確立するために, 軸対称イン テークとターボジェットエンジンより構成される超音速エ アブリージングエンジンの再始動制御実験を行った . 再始 動制御実験は, 飛行中にインテークが不始動となり, さら に燃焼火炎が消炎してしまった場合を想定し，風洞通風開 始後にエンジンを着火し, 再始動後, 全圧回復率, 回転 数，燃焼ガス温度を最大まで制御するシーケンスを行っ た . 制御実験は成功し，不始動後30〜 40secで再始動推力回 復が可能であることを示した .さらに，インテーク不始動 直後に燃焼ガス温度, 回転数が上昇するターボジェットエ ンジンの特性を示し，不始動検出後は，燃料供給を強制的 に遮断する制御ロジックを提案した．また，不始動中にイ ンテークバズが発生し，燃焼火炎が消炎する現象を示し， バズ回避のために新たにバズマージンを制御量とする制御 方法を提案した。

\section{参 考 文 献}

1) Taguchi, H : A Study on Pre-Cooled Turbojet-Scramjet - Rocket Combined Engines, A IA A Paper 98-3777, 1998

2) 野村茂昭：将来型宇宙輸送システムの研究開発の方向性，第 44回宇宙科学技術連合講演会, 2000.

3) 宇宙科学研究所将来型宇宙輸送システムサブワーキングルー プ編: ATREXエンジンを用いた 2 段式スペースプレーンの実 証計画, 1998

4) Campbell, D : F-12 Series A ircraft Propulsion System Performance and Development, J. A ircraft, 11(1974), pp670-676

5) Seddon, J : Intake A erodynamics, AIAA Educational Series, W ashington, 1989, pp149-168.

6) Sato, $T$ : Development Study on the ATREX Engine, IAF-OO
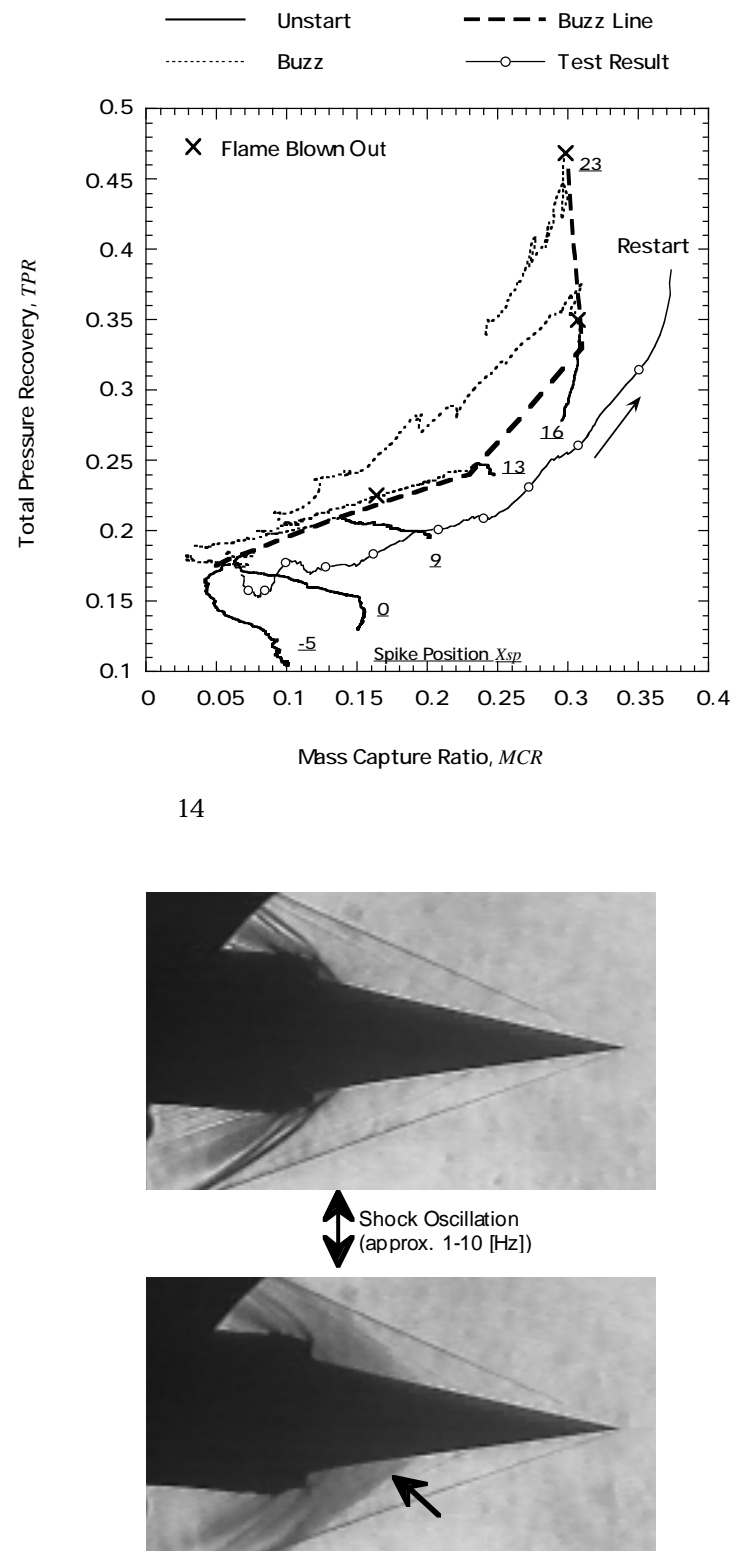

第15図 インテークバズのシュリーレン映像

S.5.02

,Rio de Janeiro, 2000

7) Kojima, T : Experimental Study on Inlet Control System for Hypersonic Flight, IST S 2000-a 08, Morioka, 2000.

8) Takagi, I : Development Study on A ir Intake for ATREX Engine, International Symposium on A ir Breathing Engines, 1997.

9) 小島孝之：超音速可変軸対称エアインテークに関する研究， 第38回航空原動機・宇宙推進講演会講演集, 1998, pp.115-120.

10) 小島孝之 : ATREXエアインテークの研究開発,第40回航空原 動機・宇宙推進講演会講演集, 2000, pp.263 268.

11) L efebvre, A. H. : ガスタービン燃焼工学, 目刊工業新聞社, 東 京, 1994, pp.1-91.

12) 長島利夫：ガスタービンエンジン , 朝倉書店, 東京, 2000 , pp.78-113.

13) Jack D. Mattingly : A ircraft Engine Design, AIAA Educational Series, Washington, 1988, pp.219-432. 